\title{
Genetic diversity and structure of native maize races from Northwestern Mexico
}

\author{
Isrrael Vega-Alvarez ${ }^{(1)}$, Amalio Santacruz-Varela(1), Mario Rocandio-Rodríguez ${ }^{(2)}$, Leobigildo Córdova-Téllez ${ }^{(1)}$,
} Higinio López-Sánchez ${ }^{(3)}$, Abel Muñoz-Orozco ${ }^{(1)}$ and Aurelio Hernández-Bautista ${ }^{(1)}$

\begin{abstract}
(1)Colegio de Postgraduados, Campus Montecillo, Carretera México-Texcoco, Km 36.5, C. P. 56230 Texcoco, Estado de México, México. E-mail: isrrael.vega@colpos.mx, asvarela@colpos.mx, Icordova@colpos.mx, amunozo@colpos.mx, aureliohb@hotmail.com(2)Universidad Autónoma de Tamaulipas, Instituto de Ecología Aplicada, División del Golfo 356, C.P. 87019 Ciudad Victoria, Tamaulipas, México. E-mail: mrocandio@docentes.uat.edu.mx ${ }^{(3)}$ Colegio de Postgraduados, Campus Puebla, Carretera México-Puebla, Km 125.5, C.P. 72760 Santiago Momoxpan, Puebla, México. E-mail: higiniols@colpos.mx
\end{abstract}

Abstract - The objective of this work was to evaluate the genetic diversity of nine maize races (Zea mays ssp. mays) from Northwestern Mexico and one population of teosinte of the Balsas race (Zea mays ssp. parviglumis). A total of 649 alleles were identified, with an average of 20.9 alleles per locus using 31 microsatellite loci; $84.3 \%$ of them were polymorphic loci with a 0.49 expected heterozygosity. Graphic representation of principal coordinate analysis (PCoA) showed broad variation and population distribution. The highest probabilistic value obtained with the $\Delta \mathrm{K}$ criterion confirmed the existence of five population groups clustered by the Bayesian model. This grouping coincided with the population distribution observed in the PCoA graph. Maize races examined retain broad genetic diversity among and within the evaluated populations.

Index terms: Zea mays, conservation strategies, landraces, microsatellites, plant breeding.

\section{Diversidade genética e estrutura das raças de milho nativo do Noroeste do México}

Resumo - O objetivo deste trabalho foi avaliar a diversidade genética de nove raças de milho (Zea mays ssp. mays) do Noroeste do México e uma população de teosinto da raça Balsas (Zea mays ssp. parviglumis). Foram identificados 649 alelos, uma média de 20,9 alelos por locus, utilizando 31 loci microssatélites. Desses, 84,3\% eram polimórficos e apresentaram heterozigosidade esperada de 0,49. A representação gráfica da análise de fatores principais (PCoA) mostrou ampla variação e distribuição populacional. O maior valor probabilístico obtido com o critério $\Delta \mathrm{K}$ confirmou a existência dos cinco grupos populacionais agrupados com o modelo bayesiano. Esse agrupamento coincide com a distribuição populacional observada no gráfico PCoA. As raças de milho examinadas apresentam ampla diversidade genética entre e dentro das populações avaliadas.

Termos para indexação: Zea mays, estratégias conservacionistas, raças nativas, microssatélites, melhoramento vegetal.

\section{Introduction}

Mexico is a territory in which a broad diversity of maize (Zea mays ssp. mays L.) still exists, thus forming an enormous mosaic of wild relatives, native landraces and, after the Green Revolution, improved varieties (Kato Yamakake et al., 2009). Maize was domesticated in Southwestern Mexico in the Balsas river basin more than 9,000 years ago. The domesticated variety derived from perennial teosinte (Zea mays ssp. parviglumis Iltis \& Doebley) (Van Heerwaarden et al., 2011). At least 59 maize races have been described in Mexico and related by origin and distribution to specific geographic regions (Vielle-Calzada \& Padilla, 2009).
In Mexico, maize is grown on 7.6 million hectares, which is equivalent to more than a third of the cultivated area of the country (SIAP, 2016). Of this area, it is estimated that $76.5 \%$ is planted to native landraces (Herrera et al., 2002). Distribution of most of the races has remained stable over the last 60 years; however, a sharp reduction in the populations of several races has been reported, including some races from the Northwest, such as Chapalote, Dulcillo del Noroeste, Jala and Onaveño, which have been classified under the status of high risk of extinction (Perales \& Golicher, 2014). Conservation of genetic diversity by traditional farmers is of great relevance since the processes of 
evolution and adaptation go along with changes in their surroundings. Moreover, this diversity is an important source for assuring food security for many farmers. It is also a source of alleles that might be useful in plant breeding programs (Salhuana \& Pollak, 2006).

The maize races from Northwestern Mexico have been described by their morphological traits (Wellhausen et al., 1952; Sanchez G.\& Goodman 1992), biochemical markers (Doebley et al., 1985; Sanchez G. et al., 2000) and molecular markers (Reif et al., 2006; Pineda-Hidalgo et al., 2013); however, these studies used small samples (in terms of the number of individuals per population and populations per race), fewer markers and a small geographic coverage, which are significant aspects that affect the estimation reliability of the population diversity parameters (Bashalkhanov et al., 2009; Van Inghelandt et al., 2010). Thus, the evaluation of a larger number of populations per race and the collection of populations within a broader geographic coverage are necessary.

Microsatellites have been efficient tools in determining the genetic diversity and structure of populations of native maize landraces and improved lines (Vigouroux et al., 2008; Warburton et al., 2008); in a situation of similar single nucleotide polymorphism (SNP) and simple sequence repeats (SSR) numbers, microsatellites are 7 to 11 times more precise than SNPs (Van Inghelandt et al., 2010). They are also used in breeding to identify desirable alleles, to select germplasm sources and to identify heterotic groups (Lago et al., 2014; Surender et al., 2014). For the Jala maize landrace, these markers have been used to estimate the effects of in situ and ex situ conservation (Rice, 2004).

The objectives of this work were to estimate the genetic diversity and structure of 107 populations belonging to nine native maize races as well as one population of teocinte to determine the distribution of diversity within and among populations, and to deduce relationships of similarity among the landraces and populations analyzed.

\section{Materials and Methods}

A total of 107 native maize populations, represented by 25 plants each, were analyzed. These populations belonged to nine races from the Northwestern Mexico (Figure 1). The number of populations per race were as follows: 12 of the Blandito race, 13 of the Chapalote race, 13 of the Dulcillo del Noroeste race, 4 of the Elotero de Sinaloa race, 6 of the Jala race, 11 of the Onaveño race, 10 of the Reventador race, 23 of the Tabloncillo race, and 15 of the Vandeño race. Racial identification of the populations was taken from the passport data available at the International Maize and Wheat Improvement Center (El Batan, Mexico state, Mexico). The seeds used were obtained from the germplasm banks of the International Maize and Wheat Improvement Center and of the Instituto Nacional de Investigaciones Forestales, Agrícolas y Pecuarias (State of Mexico, Mexico). In addition, a population of teosinte of the Balsas race (Zea mays ssp. parviglumis Iltis \& Doebley) collected in Huetamo, Michoacán, Mexico, was included.

Maize seeds were germinated using wet paper towels into a growth chamber and grown at $25 \pm 2{ }^{\circ} \mathrm{C}$ with $80 \%$ of relative humidity during 7 days. Genomic DNA was extracted from $100 \mathrm{mg}$ of mesocotyl, coleoptile and leaf tissue from 255 -day-old seedlings per populations using a commercial kit (ChargeSwitch gDNA Plant, Invitrogen, Carlsbad, California, USA) and following the procedure indicated by the manufacturer. Extracts were purified with a KingFisher Flex robot (Thermo Fisher Scientific, Waltham, Massachusetts, USA). DNA quality was measured with an ultra-low volume spectrophotometer NanoDrop 2000 (Thermo Scientific, Waltham, Massachusetts, USA), with absorbance readings at 260 and $280 \mathrm{~nm}$. Polymerase chain reaction (PCR) was individually performed in each plant.

In total, 31 microsatellite loci marked with fluorescent labels at the 5' end of the forward primer were used. Using these molecular markers, multiplex PCR was performed according to the following groups: Group 1 (phi127:NED, phi051:6-FAM, phil15:HEX, phi015:HEX, phi033:6-FAM), Group 2 (phi053:NED, phi072:6-FAM, phi093:NED, phi024:HEX, phi085:6-FAM, phi034:HEX, phi121:6-FAM), Group 3 (phi056:NED, phi064:HEX, phi050:NED), Group 4 (phi96100:6-FAM, phi101249:6-FAM, phi109188:HEX), Grupo 5 (phi029:NED, phi073:HEX, phi96342:6-FAM, phi109275:6-FAM), Grupo 6 (phi427913:NED, phi265454:6-FAM, phi402893:HEX), Group 7 (phi346482:HEX, phi308090:6-FAM, phi330507:NED), Group 8 (phi3398:6-FAM phi339017:HEX, phi159819:6-FAM), as described in 
detail in the Maize Genetics and Genomics Database (MaizeGDB, 2016). Amplification by multiple PCR was performed in volumes of $25 \mu \mathrm{L}$, which contained $5 \mathrm{x}$ buffer, $25 \mathrm{mM} \mathrm{MgCl}, 10 \mathrm{mM}$ dNTPs, $4 \mathrm{pM}$ of each primer, one unit of DNA Taq polymerase, $25 \mathrm{ng}$ template DNA, and HPLC grade water. Amplification by PCR consisted of one initial denaturation for 4 min at $95^{\circ} \mathrm{C}$, followed by 25 cycles of $1 \mathrm{~min}$ at $95^{\circ} \mathrm{C}$, $2 \mathrm{~min}$ at $55^{\circ} \mathrm{C}, 2 \mathrm{~min}$ at $72^{\circ} \mathrm{C}$ and one final extension of $60 \mathrm{~min}$ at $72^{\circ} \mathrm{C}$. PCR products were separated by capillary electrophoresis in a DNA sequencer (Genetic Analyzer ABI 3130, Applied Biosystems, Foster City, California, USA) using $0.25 \mu \mathrm{L}$ of $500 \mathrm{LIZ}$ dye size standard. SSR alleles were identified with GeneMapper V. 4.0 software (Applied Biosystems, 2005), and the size of the fragments was determined as the number of nucleotides amplified of each sample.

Allele frequencies were obtained for each population, and the following diversity parameters were determined: number of alleles per locus, proportion of

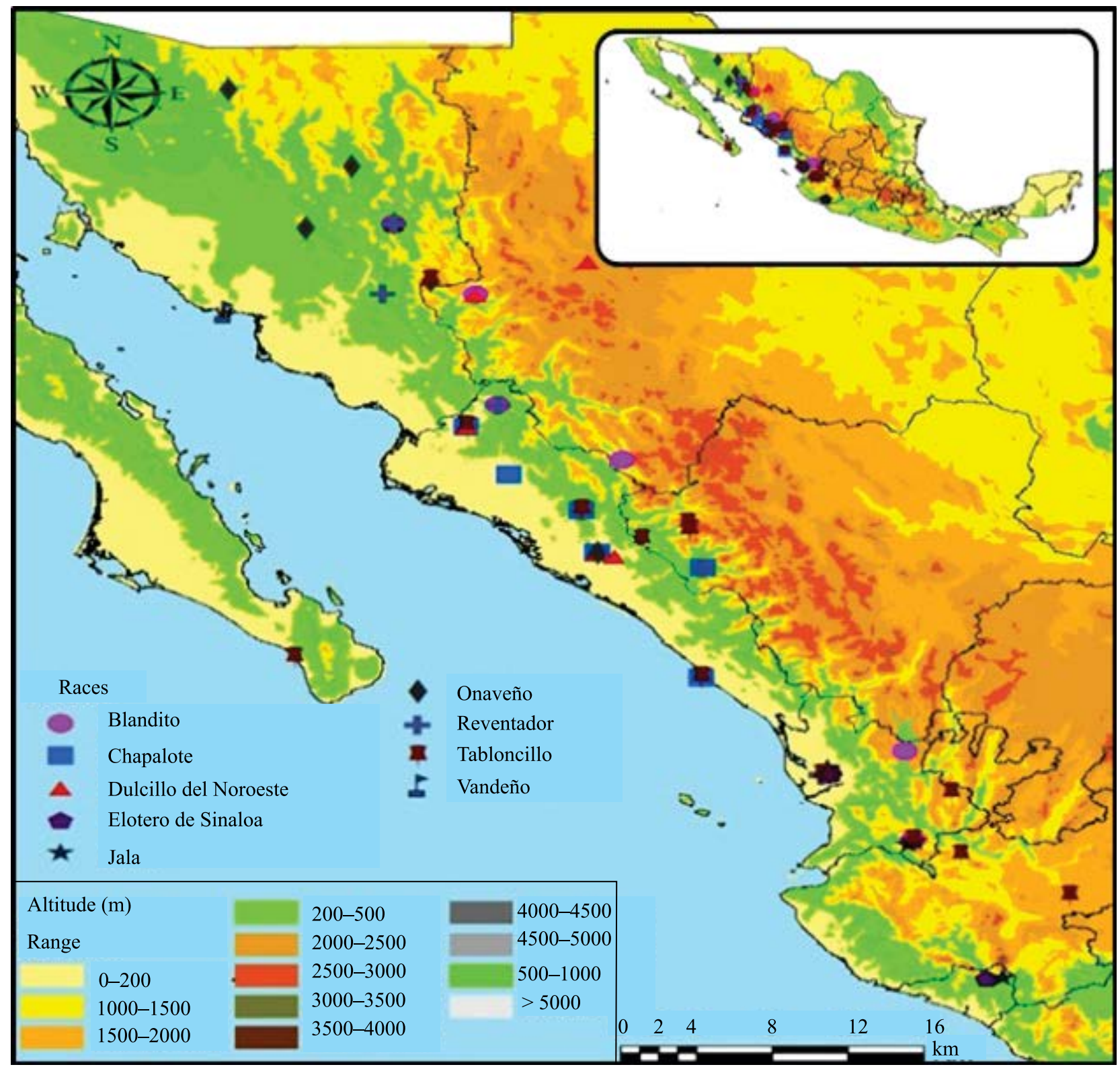

Figure 1. Origin sites of the evaluated populations. 
polymorphic loci and expected heterozygosity. The genetic structure of the populations was estimated with Wright's (1965) F-statistics ( $F_{\mathrm{IS}}, F_{\mathrm{ST}}$, and $F_{\text {IT }}$ ) using Popgene V.1.32 software (Yeh et al., 1999).

Population structure was inferred based on a Bayesian clustering analysis with Structure 2.3.4 software (Pritchard et al., 2000); all individuals of the ten races (including teosinte) were analyzed using a mixed model with correlated allele frequencies. In this model, estimation of the $\lambda$ parameter was carried out assuming a subgroup $(K=1)$ where $K$ was run five times with a fixed duration of re-samplings and 100,000 Markov chain Monte Carlo (MCMC) repetitions. The number of likely groupings $(\mathrm{K})$ within the population studied (2,700 plants) was determined with the methods proposed by Evanno et al. (2005) and Rosenberg et al. (2001) and applied using Structure Harvester (Earl \& von Holdt, 2012). For each of the five identified clusters, a belonging likelihood of $\geq 0.9$ was fixed to assign plants to the group previously identified by the program; those individual plants with a value $<$ 0.9 were assigned to a mixed group (Vigouroux et al., 2008). Finally, the clusters were visualized and edited with the Distruct software (Rosenberg, 2004).

Principal coordinate analysis ( $\mathrm{PCoA})$ was performed with GenAlex 6 software (Peakall \& Smouse, 2006) to determine similarity patterns among the 108 populations. A phylogram was constructed using allele frequencies and the teosinte population as an outgroup. The neighbor-joining grouping method (Saitou \& Nei,
1987) was applied using modified Rogers' genetic distances (Wright, 1978). These analyses were performed with NTSYSpc software V. 2.21c (Rohlf, 2009).

\section{Results and Discussion}

The analyzed populations contained 649 SSR alleles, resulting in a total of 20.9 alleles per locus (Table 1) ranging from 7 (in the phil15 marker) to 39 alleles (in the phi064 and phi402893 markers). RocandioRodríguez et al. (2014) estimated the genetic diversity of seven corn races represented in 107 populations in the high valleys of Mexico. They used the same markers used in the present work and obtained similar results: a total of 636 alleles, with an average of 20.5 alleles per locus. In contrast, Reif et al. (2006) detected 196 SSR alleles and an average of 7.8 alleles per locus using 25 markers in the 24 native landraces of Mexico described by Wellhausen et al. (1952).

Data were compared with those of studies with similar number of plants and markers, and, even so, there are notable differences. Among the most probable factors that contributed to detecting greater polymorphism in this study are the specific group of markers used, the rich evolutionary history of Mexican maize, and the automated method of allele detection, which is capable of detecting differences in alleles at the level of individual nucleotide (Reif et al., 2006). The mean proportion of polymorphic loci in the ten

Table 1. Parameters of genetic diversity of nine native maize races (Zea mays ssp. mays) and one teosinte race (Zea mays ssp. parviglumis), based on 31 simple sequence repeat (SSR) loci.

\begin{tabular}{|c|c|c|c|c|c|}
\hline Race & $\begin{array}{l}\text { Number of } \\
\text { populations }\end{array}$ & $\begin{array}{c}\text { Number of } \\
\text { alleles }\end{array}$ & $\begin{array}{c}\text { Number of alleles } \\
\text { per locus }\end{array}$ & $\begin{array}{l}\text { Polymorphic } \\
\text { loci }(\%)\end{array}$ & $\mathrm{He}^{(1)}$ \\
\hline Blandito & 12 & 303 & 12.9 & 88.4 & 0.53 \\
\hline Chapalote & 13 & 287 & 12.2 & 90.8 & 0.46 \\
\hline Dulcillo del Noroeste & 13 & 265 & 11.1 & 63.5 & 0.42 \\
\hline Elotero de Sinaloa & 4 & 278 & 9.0 & 80.6 & 0.48 \\
\hline Jala & 6 & 225 & 9.5 & 77.4 & 0.47 \\
\hline Onaveño & 11 & 303 & 11.9 & 82.7 & 0.54 \\
\hline Reventador & 10 & 283 & 11.3 & 82.6 & 0.54 \\
\hline Tabloncillo & 23 & 312 & 14.4 & 80.2 & 0.53 \\
\hline Vandeño & 15 & 296 & 13.8 & 97.2 & 0.50 \\
\hline Balsas (teosinte) & 1 & 164 & 5.2 & 100 & 0.43 \\
\hline Total & 108 & 649 & 20.9 & - & - \\
\hline Mean & - & - & - & 84.3 & 0.49 \\
\hline
\end{tabular}

${ }^{(1)} \mathrm{He}$, Expected heterozygosity. 
analyzed races was $84.3 \%$. The higher values were found in the Vandeño race $(97.2 \%)$, and the lowest ones in Jala and Dulcillo del Noroeste races (Table 1). The percentage of polymorphic loci in the teosinte race was $100 \%$, thus demonstrating the existence of bottlenecks during the process of maize domestication that reduced genetic diversity to $19.1 \%$ on average.

Expected heterozygosity for the different races showed broad genetic diversity, with an average of 0.49 . This differs slightly from findings in other studies, such as that of González Castro et al. (2013), who reported a value of 0.57 in 20 tropical native races of Mexico, or that of Lia et al. (2009), who also found 0.57 in six native races of Argentina. Calculated parameter values based on the ten races of this study showed considerable genetic diversity and justify establishing programs for conservation of these races.

Population differentiation was estimated with the $\mathrm{F}_{\mathrm{ST}}$ statistics, with an average value of 0.328 (Table 2) for the ten races, thus evidencing that there is high differentiation among the populations due to geographic distance and divergence time. In contrast, Pressoir \& Berthaud (2004) reported an $\mathrm{F}_{\mathrm{ST}}$ of just 0.011 for 31 corn populations from six locations of the Central Valleys of Oaxaca, Mexico. The lowest value in our study was for the Vandeño race, while the Dulcillo del Noroeste race showed the greatest differentiation among populations. The Jala race had the second lowest differentiation value among populations, which coincides with its highly specific adaptation, limited to

Table 2. Wright's F-statistics of nine native maize races (Zea mays ssp. mays) from Northwestern Mexico and one teosinte (Balsas) race (Zea mays ssp. parviglumis $)^{(1)}$.

\begin{tabular}{lccc}
\hline Race & $\mathrm{F}_{\mathrm{IS}}$ & $\mathrm{F}_{\mathrm{IT}}$ & $\mathrm{F}_{\mathrm{ST}}$ \\
\hline Blandito & 0.148 & 0.369 & 0.260 \\
Chapalote & 0.179 & 0.433 & 0.310 \\
Dulcillo del Noroeste & 0.198 & 0.649 & 0.562 \\
Elotero de Sinaloa & 0.169 & 0.486 & 0.382 \\
Jala & 0.251 & 0.421 & 0.227 \\
Onaveño & 0.130 & 0.424 & 0.338 \\
Reventador & 0.107 & 0.418 & 0.348 \\
Tabloncillo & 0.158 & 0.463 & 0.362 \\
Vandeño & 0.196 & 0.329 & 0.166 \\
Balsas & 0.318 & 0.318 & - \\
\hline Average & 0.185 & 0.431 & 0.328 \\
\hline
\end{tabular}

${ }^{(1)} \mathrm{F}_{\text {IS }}$, Endogamy within populations; $\mathrm{F}_{\text {IT }}$, Endogamy of the total population; $\mathrm{F}_{\mathrm{ST}}$, Coefficient of differentiation. the Jala Valley, state of Nayarit, where it is cultivated in an area of not more than 30 ha (Montes-Hernández et al., 2014). This race had the highest individual endogamy index within the populations; probably this is the reason why the long ears that were characteristic of the race no longer frequently appear (AguilarCastillo et al., 2006).

Graphic representation of PCoA showed broad variation among populations distributed in the four quadrants (Figure 2). The first axis explained $21.5 \%$ of the variation and separated three groups: the Jala race; the Vandeño, Reventador, Chapalote and Tabloncillo races, which formed a cluster in the central part of the diagram; and some populations of the Dulcillo del Noroeste races in the positive end of the axis. The second axis explained $9.2 \%$ of the variation, but there was no clear separation of races. There was a group of the Vandeño, Reventador, Chapalote and Tabloncillo races, which indicated genetic similarity among them, coinciding with their similar geographic distribution. PCoA explained only less than $30.7 \%$ of the variation. This might partly result from incomplete linkage between major genes and molecular markers used in the presented study.

Using the likelihood method, the highest number of likely groupings $(\mathrm{K})$ was obtained when $\mathrm{K}=5$, and thereafter, likelihood values remained constant. Moreover, applying the Evanno et al. (2005) criterion, the highest value of $\Delta \mathrm{K}$ was obtained at $\mathrm{K}=2$, while the second highest peak was observed at $\mathrm{K}=5$. However, the highest value of $\Delta \mathrm{K}$ (at $\mathrm{K}=2$ ) may be considered spurious because of the high number of loci evaluated in the population, which caused the null hypothesis to be refuted (Vigouroux et al., 2008). Therefore, the value at $\mathrm{K}=5$ was considered the one which best fitted the population structure, which is similar to that shown by PCoA.

Based on the $\geq 0.9$ threshold to assign each plant to a group and taking into account the highest population values of each race $(\mathrm{Q})$, the arrangement into five groups (Figure 3) was defined as follows: Group 1 represented mostly by Chapalote $(\mathrm{Q}=0.63)$ and Elotero del Sinaloa $(\mathrm{Q}=0.71)$ and comprising 316 plants; Group 2 included Balsas and Onaveño $(\mathrm{Q}=0.98$ and 0.55 , respectively) and comprised 235 plants; Group 3 represented by Vandeño $(\mathrm{Q}=0.76)$ and comprised 214 plants; Group 4, the largest group, included Blandito $(\mathrm{Q}=0.71)$ and Reventador $(\mathrm{Q}=0.75)$ and comprised 399 plants; and

Pesq. agropec. bras., Brasília, v.52, n.11, p.1023-1032, nov. 2017 DOI: $10.1590 / \mathrm{S} 0100-204 X 2017001100008$ 
Group 5 represented by Dulcillo del Noroeste, Jala and Tabloncillo $(\mathrm{Q}=0.43,0.73$ and 0.37 , respectively) and comprised 244 plants.

Based on morphological characteristics, Wellhausen et al. (1952) suggested that some of the landraces had emerged from hybridization of other previously existing races. They proposed Chapalote as one of the progenitors of Reventador, and the latter as a progenitor of Tabloncillo. The results obtained indicated that the populations of Reventador share a low to medium percentage of kinship with populations of the Chapalote race, as well as those of Tabloncillo with populations of Reventador, thus confirming that, in these races, there had been a genetic drift. Wellhausen et al. (1952) also proposed that the Jala race was a hybrid of the cross Tabloncillo $\times$ Comiteco. In the present study, all Jala populations and more than $50 \%$ of Tabloncillo ones exhibited a high degree of genetic kinship, thus suggesting that the Jala race possesses certain fragments of the Tabloncillo genome.

The clustering with the neighbor-joining method was generated from a matrix of genetic distances based on 649 SSR alleles. In the phylogram, the origin is monophyletic, with the population of teosinte as the common ancestor (Figure 4). In the diagram, populations of the same race did not cluster consistently, thus denoting that they are undergoing divergence because of their isolation in different locations. Furthermore, gene flow among locations could be happening and leading to this inconsistency. Four main groups tended to exhibit certain association in terms of their evolutionary history and the place where they had been collected (Wellhausen et al., 1952; Sanchez G. \& Goodman, 1992).

Group 1 comprised 48 populations of the Blandito, Tabloncillo and Reventador races mainly from Sonora and Sinaloa. Blandito and Tabloncillo have Reventador

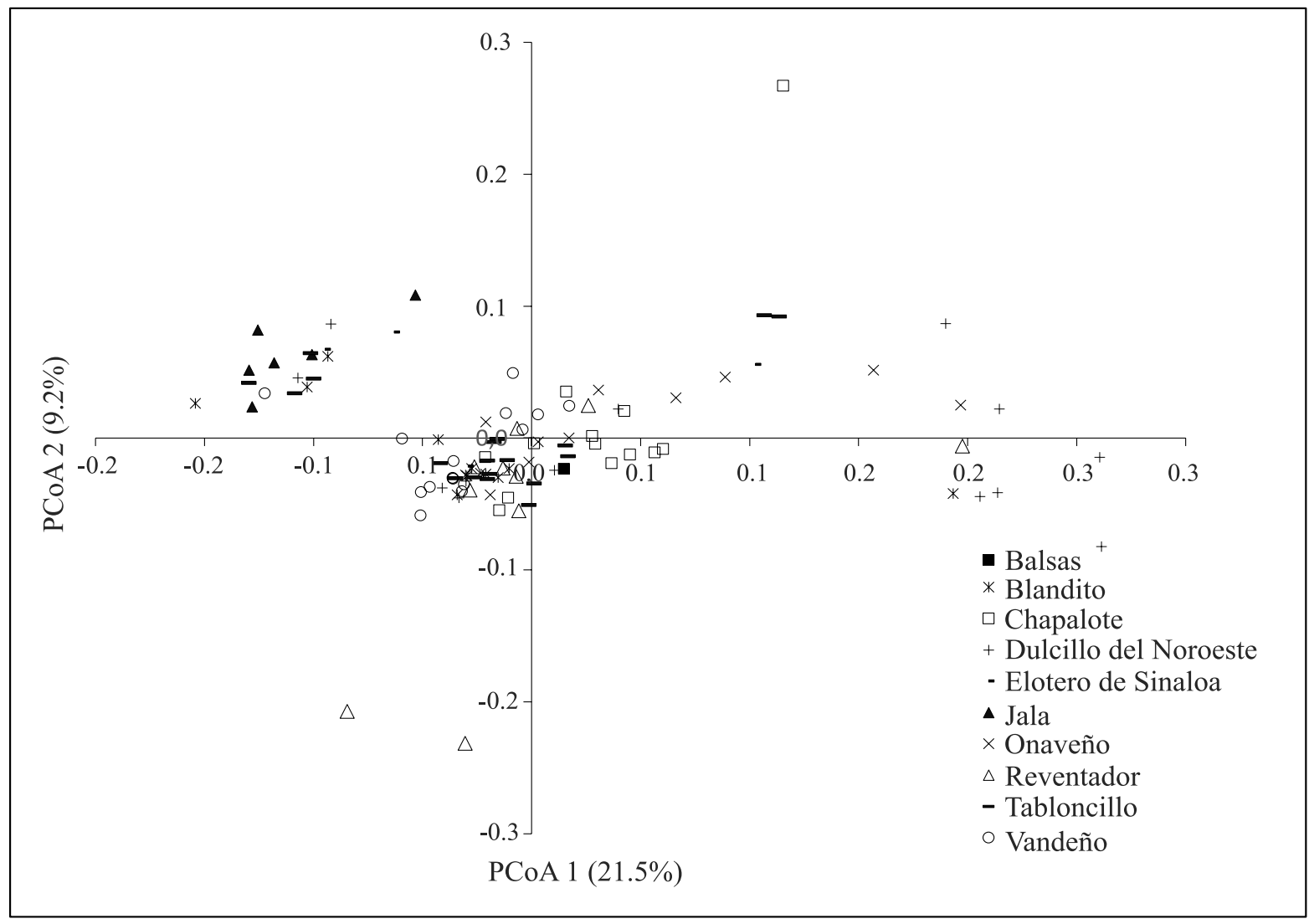

Figure 2. Relationships among 107 native maize (Zea mays ssp. mays) populations and one teosinte (Balsas) race (Zea mays ssp. parviglumis) population based on principal coordinate analysis (PCoA) derived from the allelic profile of 31 SSR loci. 
as a common ancestor combined with Chapalote and Harinoso de Ocho. This grouping was also reported by Sanchez G. \& Goodman (1992), as well as a clade formed by 13 populations, among which exists a cluster of 9 populations of Vandeño, another with 2 populations of Tabloncillo, and disperse populations of Blandito, Reventador, Chapalote, and Onaveño. An outstanding feature of this subgroup is that it has, on average, the highest percentage of polymorphic loci of the studied landraces. Another small subgroup was a set of units from a single node and it was formed by 2 populations related to Dulcillo del Noroeste, a cluster of 7 populations of Tabloncillo and 1 population of Chapalote. These populations are predominantly distributed in low altitude regions (Wellhausen et al., 1952).

Group 2 was formed by 32 populations of seven different landraces, which had been reported by other authors in different clades, with some tendencies to grouping by origin, since 12 are from the state of Nayarit, among which there were six populations of the Jala race. The group included sets of 2 to 3 populations of the same race, related by internal nodes to Blandito, Jala, Tabloncillo, and Reventador, as well as populations in unrelated nodes of the same races, including some of Vandeño, Elotero de Sinaloa, and Dulcillo del Noroeste.

Groups 3 and 4 were the closest ones to teosinte; that is, they were more genetically similar to the common ancestor. Group 3 comprised mostly populations of the Chapalote race, which was reported by Wellhausen et al. (1952) as one of the ancient indigenous races. The group also included Vandeño and Onaveño populations, characterized by their cylindrical ears, predominantly white grains and adaptation to low moisture conditions. Group 4 included Dulcillo del Noroeste and Tabloncillo populations, which share a node with Tabloncillo Perla and Onaveño, as well as separate Reventador, Elotero de Sinaloa, Chapalote and Blandito populations, which, in other studies, had been reported as belonging to different clusters.

Divergence time and progenitors of the races analyzed in this study have not been entirely established, but results reported here suggest that differentiation of the genomes of these races has taken place over a short period of time. PCoA and the phylogram showed that several of the populations have a similar genetic background, which resulted in groupings that were inconsistent with phenotypic differentiation. Results presented here also suggested that, at the molecular level, there is a diffuse genetic background that has not yet clearly led to phenotypic differentiation, which is more clearly revealed when selectively neutral molecular markers (such as SSR) are involved.

The examined maize races harbored broad genetic diversity among and within their populations. Selection pressure and genetic drift have led to a decrease in genetic variation (in this case, to 19.1\%) relative to the common ancestor. Diversity parameter values were higher than those reported in other studies on native maize because of the analyzed number of samples, the group of markers and the automated technique of allele detection. Regarding the distribution of total genetic variation, an average $66.9 \%$ of the variation was found within the populations and an average of $33.3 \%$ among populations. Geographic origin affected population differentiation and dispersion in PCoA.

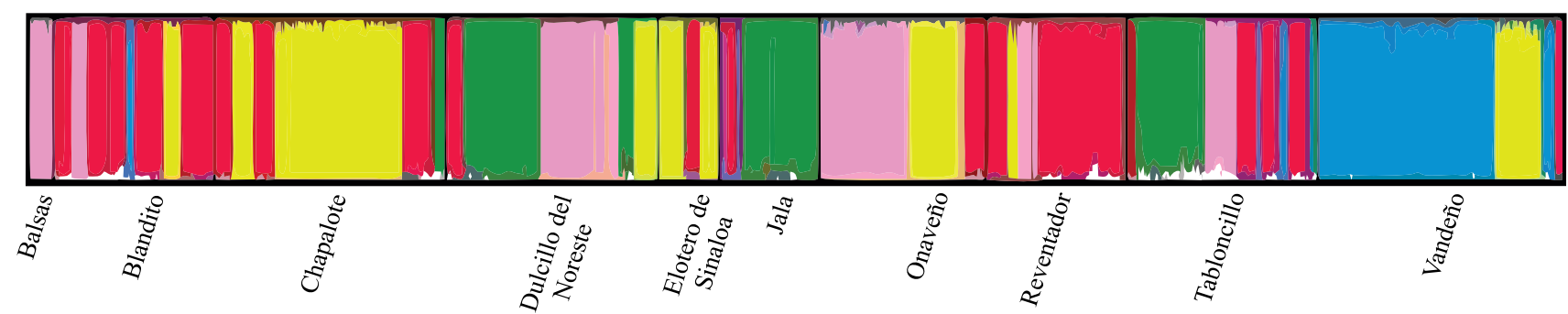

Figure 3. Five population groups of races from Northwestern Mexico (Group 1 = yellow; Group 2 = pink; Group 3 = blue; Group 4 = red; Group 5 = green), inferred by Structure analysis (Evanno et al., 2005). 


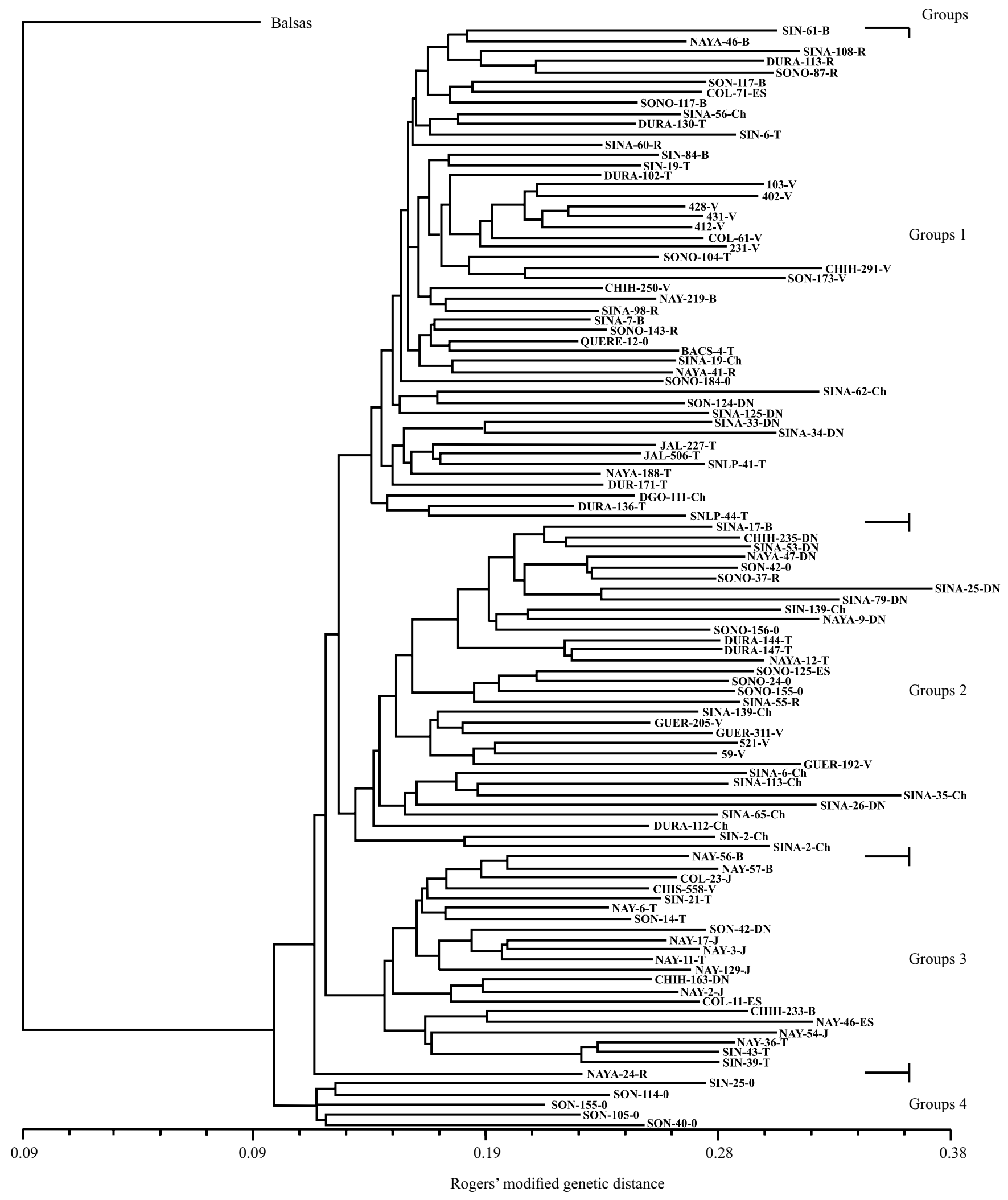

Figure 4. Phylogram of 107 native maize (Zea mays ssp. mays) populations from Northwestern Mexico and one teosinte (Zea mays ssp. parviglumis) population, constructed with the neighbor-joining clustering method using Rogers' modified genetic distances of 31 microsatellite loci. 


\section{Conclusions}

1. Maize (Zea mays ssp. mays) races from Northwestern Mexico harbor broad genetic diversity both among and within their populations, with the genetic variation within populations being larger than that among populations.

2. Average diversity parameter values are higher than those reported in other studies on native maize, which confirms that the sample size used per race allows for a more detailed detection of the allelic variability present in the races.

3. Genetic diversity found in corn populations can be used in designing conservation strategies and maximizing its use in breeding programs.

\section{Acknowledgments}

To Sistema Nacional de Recursos Fitogenéticos para la Alimentación y la Agricultura (Sinarefi) of Secretaría de Agricultura, Ganadería, Desarrollo Rural, Pesca y Alimentación of Mexico, for funding received.

\section{References}

AGUILAR-CASTILLO, J.A.; CARBALLO-CARBALLO, A.; CASTILLO-GONZÁLEZ, F.; SANTACRUZ-VARELA， A.; MEJÍA-CONTRERAS, J.A.; CROSSA-HIRIARTTE, J.; BACACASTILLO, G. Diversidad fenotípica y variantes distintivas de la raza Jala de maíz. Agricultura Técnica en México, v.32, p.57-66, 2006.

APPLIED BIOSYSTEMS. GeneMapper ${ }^{\circledR}$ Software Version 4.0: reference and troubleshooting guide. Foster, 2005. 82p.

BASHALKHANOV, S.; PANDEY, M.; RAJORA, O.P. A simple method for estimating genetic diversity in large populations from finite sample sizes. BMC Genetics, v.10, p.1-10, 2009. DOI: $10.1186 / 1471-2156-10-84$.

DOEBLEY, J.F.; GOODMAN, M.M.; STUBER, C.W. Isozyme variation in the races of maize from Mexico. American Journal of Botany, v.72, p.629-639, 1985. DOI: 10.2307/2443674.

EARL, D.A.; VONHOLDT, B.M. STRUCTURE HARVESTER: a website and program for visualizing STRUCTURE output and implementing the Evanno method. Conservation Genetics Resources,v.4, p.359-361, 2012. DOI: 10.1007/s12686-011-9548-7.

EVANNO, G.; REGNAUT, S.; GOUDET, J. Detecting the number of clusters of individuals using the software STRUCTURE: a simulation study. Molecular Ecology, v.14, p.2611-2620, 2005. DOI: $10.1111 / j .1365-294 X .2005 .02553 . x$.

GONZÁlEZ CASTRO, M.E.; PALACIOS ROJAS, N.; ESPINOZA BANDA, A.; BEDOYA SALAZAR, C.A. Diversidad genética en maíces nativos mexicanos tropicales. Revista
Fitotecnia Mexicana, v.36, (Supl. 3-A) p.329-338, 2013. Supl. 3-A.

HERRERA CABRERA, B.E.; MACÍAS-LÓPEZ, A.; DÍAZ RUÍZ, R.; VALADEZ RAMÍREZ, M.; DELGADO ALVARADO, A. Uso de semilla criolla y caracteres de mazorca para la selección de semilla de maíz en México. Revista Fitotecnia Mexicana, v.25, p.17-23, 2002.

KATO YAMAKAKE, T.A.; MAPES SÁNCHES, C.; MERA OVANDO, L.M.; SERRATOS HERNÁNDEZ, J.A.; BOETTLER, R.A.B. Origen y diversificación del maíz: una revisión analítica. México, DF: UNAM/CONABIO, 2009. 116p.

LAGO, C.; LANDONI, M.; CASSANI, E.; ATTANASSIU, S.; CANTALUPPI, E.; PILU, R. Development and characterization of a coloured sweet corn line as a new functional food. Maydica, v.59, p.191-200, 2014.

LIA, V.V.; POGGIO, L.; CONFALONIERI, V.A. Microsatellite variation in maize landraces from Northwestern Argentina: genetic diversity, population structure and racial affiliations. Theoretical and Applied Genetics, v.119, p.1053-1067, 2009. DOI: 10.1007/s00122-009-1108-0.

MAIZEGDB. Maize Genetics and Genomics Database. Available at: <http://www.maizegdb.org/ssr.php\#>. Accessed on: Dec. 142016.

MATSUOKA, Y.; VIGOUROUX, Y.; GOODMAN, M. M.; SANCHEZ, G. J.; BUCKLER, E.; DOEBLEY, J. A single domestication for maize shown by multilocus microsatellite genotyping. Proceedings of the National Academy of Sciences of the United States of America, v.99, p.6080-6084, 2002. DOI: $10.1073 /$ pnas.052125199.

PEAKALL, R.; SMOUSE, P.E. GENALEX 6: genetic analysis in Excel. Population genetic software for teaching and research. Molecular Ecology Notes, v.6, p.288-295, 2006. DOI: 10.1111/j.1471-8286.2005.01155.x.

PERALES, H.; GOLICHER, D. Mapping the diversity of maize races in Mexico. PLoS One, v.9, e114657, 2014. DOI: 10.1371/ journal.pone.0114657.

PINEDA-HIDALGO, K.V.; MÉNDEZ-MARROQUÍN, K.P.; ALVAREZ, E.V.; CHÁVEZ-ONTIVEROS, J.; SÁNCHEZPEÑA, P.; GARZÓN-TIZNADO, J.A.; VEGA-GARCÍA, M.O.; LÓPEZ-VALENZUELA, J.A. Microsatellite-based genetic diversity among accessions of maize landraces from Sinaloa in México. Hereditas, v.150, p.53-59, 2013. DOI: 10.1111/j.16015223.2013.00019.x.

PRESSOIR, G.; BERTHAUD, J. Patterns of population structure in maize landraces from the Central Valleys of Oaxaca in Mexico. Heredity, v.92, p.88-94, 2004. DOI: 10.1038/sj.hdy.6800387.

PRITCHARD, J.K.; STEPHENS, M.; DONNELLY, P. Inference of population structure using multilocus genotype data. Genetics, v.155, p.945-959, 2000.

REIF, J.C.; WARBURTON, M.L.; XIA, X.C.; HOISINGTON, D.A.; CROSSA, J.; TABA, S.; MUMINOVIĆ, J.; BOHN, M.; FRISCH, M.; MELCHINGER, A.E. Grouping of accessions of Mexican races of maize revisited with SSR markers. Theoretical 
and Applied Genetics, v.113, p.177-185, 2006. DOI: 10.1007/ s00122-006-0283-5.

RICE, B.E. Conservation and change: a comparison of in situ and ex situ conservation of Jala maize germplasm in Mexico. 2004. 120p. Dissertation (Doctor) - Cornell University, Ithaca.

ROCANDIO-RODRÍGUEZ, M.; SANTACRUZ-VARELA, A.; CÓRDOVA-TÉLLEZ, L.; LÓPEZ-SÁNCHEZ, H.; CASTILLOGONZÁLEZ, F.; LOBATO-ORTIZ, R.; GARCÍA-ZAVALA, J.J. Detection of genetic diversity of seven maize races from the high central valleys of Mexico using microsatellites. Maydica, v.59, p.144-151, 2014.

ROHLF, F.J. NTSYSpc: numerical taxonomy system: version 2.21c. Setauket: Exeter Software, 2009.

ROSENBERG, N.A. DISTRUCT: a program for the graphical display of population structure. Molecular Ecology Notes, v.4, p.137-138, 2004. DOI: 10.1046/j.1471-8286.2003.00566.x.

ROSENBERG, N.A.; BURKE, T.; ELO, K.; FELDMANN, M.W.; FREIDLIN, P.J.; GROENEN, M.A.M.; HILLEL, J.; MÄKI-TANILA, A.; TIXIER-BOICHARD, M.; VIGNAL, A.; WIMMERS, K.; WEIGEND, S. Empirical evaluation of genetic clustering methods using multilocus genotypes from 20 chicken breeds. Genetics, v.159, p.699-713, 2001.

SAITOU, N.; NEI, M. The Neighbor-joining method: a new method for reconstructing phylogenetic trees. Molecular Biology and Evolution, v.4, p.406-425, 1987.

SALHUANA, W.; POLLAK, L. Latin American maize project (LAMP) and germplasm enhancement of maize (GEM) project: generating useful breeding germplasm. Maydica, v.51, p.339-355, 2006.

SANCHEZ G., J.J.; GOODMAN, M.M. Relationships among the Mexican races of maize. Economic Botany, v.46, p.72-85, 1992. DOI: $10.1007 / \mathrm{BF} 02985256$.

SANCHEZ G., J.J.; GOODMAN, M.M.; STUBER, C.W. Isozymatic and morphological diversity in the races of maize of Mexico. Economic Botany, v.54, p.43-59, 2000. DOI: 10.1007/ BF02866599.

SIAP. Servicio de Información Agroalimentaria y Pesquera. Avance de siembras y cosechas: resumen nacional por cultivo. México, D.F.: Sagarpa, 2016. Available at: $<$ http://infosiap.siap.gob. $\mathrm{mx}: 8080$ /agricola_siap_gobmx/AvanceNacionalSinPrograma. do; jsessionid=7FE86E62040389FC7709F9A5FCDF1473>. Accessed on: Nov. 102016.

SURENDER, M.; SOKKA REDDY, S.; SUDARSHAN, M.R.; DURGARANI, C.V. Gene specific SSR marker for detection of
OPAQUE-2 alleles for conservation of non-QPM lines for QPM development. Research Journal of Agricultural Sciences, v.5, p.666-669, 2014.

VAN HEERWAARDEN, J.; DOEBLEY, J.; BRIGGS, W.H.; GLAUBITZ, J.C.; GOODMAN, M.M.; SANCHEZ GONZALEZ, J. de J.; ROSS-IBARRA, J. Genetic signals of origin, spread, and introgression in a large sample of maize landraces. Proceedings of the National Academy of Sciences of the United States of America, v. 108, p.1088-1092, 2011. DOI: 10.1073/ pnas.1013011108.

VAN INGHELANDT, D.; MELCHINGER, A.E.; LEBRETON, C.; STICH, B. Population structure and genetic diversity in a commercial maize breeding program assessed with SSR and SNP markers. Theoretical and Applied Genetics, v.120, p.1289-1299, 2010. DOI: 10.1007/s00122-009-1256-2.

VIELLE-CALZADA, J.-P.; PADILLA, J. The Mexican landraces: description, classification and diversity. In: BENNETZEN, J.L.; HAKE, S.C. (Ed.). Handbook of maize: its biology. New York: Springer, 2009. p.543-561. DOI: 10.1007/978-0-387-79418-1_27.

VIGOUROUX, Y.; GLAUBITZ, J.C.; MATSUOKA, Y.; GOODMAN, M.M.; SÁNCHEZ G., J.; DOEBLEY, J. Population structure and genetic diversity of New World maize races assessed by DNA microsatellites. American Journal of Botany, v.95, p.1240-1253, 2008. DOI: 10.3732/ajb.0800097.

WARBURTON, M.L.; REIF, J.C.; FRISCH, M.; BOHN, M.; BEDOYA, C.; XIA, X.C.; CROSSA, J.; FRANCO, J.; HOISINGTON, D.; PIXLEY, K.; TABA, S.; MELCHINGER, A.E. Genetic diversity in CIMMYT nontemperate maize germplasm: landraces, open pollinated varieties, and inbred lines. Crop Science, v.48, p.617-624, 2008. DOI: 10.2135/ cropsci2007.02.0103.

WELLHAUSEN, E.J.; ROBERTS, L.M.; HERNÁNDEZ, X.E.; MANGELSDORF, P.C. Races of maize in Mexico: their origin, characteristics and distribution. Cambridge: The Bussey Institution of Harvard University, 1952. 223p.

WRIGHT, S. Evolution and the genetics of populations: a treatise in four volumes: variability within and among natural populations. Chicago: University of Chicago, 1978. v.4, 590p.

WRIGHT, S. The interpretation of population structure by F-statistics with special regard to systems of mating. Evolution, v.19, p.395-420, 1965.

YEH, F.C.; YANG, R.-C.; BOYLE, T. POPGENE version 1.31: Microsoft Window-based freeware for population genetic analysis: quick user guide. Edmonton: University of Alberta, 1999. 28p.

$\overline{\text { Received on December 14, } 2016 \text { and accepted on April 4, } 2017}$ 